\title{
RESEARCH
}

\section{Mortality attributable to nosocomial Clostridium difficile-associated disease during an epidemic caused by a hypervirulent strain in Quebec}

\author{
Jacques Pépin, Louis Valiquette, Benoit Cossette \\ Fast-tracked article. Early release, published at www.cmaj.ca on Sept. 22, 2005. Revised Sept. 29, 2005
}

\section{ABSTRACT:}

Background: Since 2002 an epidemic of Clostridium difficile-associated disease (CDAD) caused by a hypervirulent toxinotype III ribotype 027 strain has spread to many hospitals in Quebec. The strain has also been found in the United States, the United Kingdom and the Netherlands. The effects of this epidemic on mortality and duration of hospital stay remain unknown. We measured these effects among patients admitted to a hospital in Quebec during 2003 and 2004.

Methods: We compared mortality and total length of hospital stay among inpatients in whom nosocomial CDAD developed and among control subjects without CDAD matched for sex, age, Charlson Comorbidity Index score and length of hospital stay up to the diagnosis of CDAD in the corresponding case.

Results: Thirty days after diagnosis $23.0 \%(37 / 161)$ of the patients with CDAD had died, compared with $7.0 \%(46 / 656)$ of the matched control subjects $(p<0.001)$. Twelve months after diagnosis, mortality was $37.3 \%(60 / 161)$ among patients with CDAD and $20.6 \%(135 / 656)$ among the control subjects ( $p<$ 0.001 ), for a cumulative attributable mortality of $16.7 \%$ ( $95 \%$ confidence interval $8.6 \%-25.2 \%)$. Each case of nosocomial CDAD led, on average, to 10.7 additional days in hospital.

Interpretation: This study documented a high attributable mortality among elderly patients with CDAD mostly caused by a hypervirulent strain, which represents a dramatic change in the severity of this infection.

Cite this article as $C M A J$ 2005;173(9). DOI:I0.1503/cmaj.050978

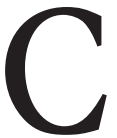

lostridium difficile-associated disease (CDAD) is endemic in Canadian hospitals. In 1995 its nationwide incidence was estimated at 3.6 per io $000 \mathrm{pa}-$ tient-days. ${ }^{1}$ Since the end of 2002, an epidemic of CDAD caused by a hypervirulent strain of $C$. difficile has spread into many hospitals in the province of Quebec, especially in the Montréal area..$^{-8}$ In January 2005, 30 hospitals in Quebec had a rate of nosocomial CDAD higher than 15 per Io 000 patient- days. ${ }^{6}$ In Sherbrooke, a city I $40 \mathrm{~km}$ southeast of Montréal, the incidence among people aged 65 years or more increased rofold between I99I and 2003, reaching a rate of 866.5 per Ioo ooo inhabitants, mostly through nosocomial transmission. ${ }^{4}$ The predominant strain in Quebec is a hyperproducer of toxins A and B, ${ }^{9}$ inducing severe diarrhea that may facilitate its transmission by incontinent patients. Other factors that have potentially contributed to the emergence of this strain are the increasing size of the population of elderly inpatients with numerous comorbidities, chronic underinvestment in hospital infrastructures, suboptimal response to metronidazole therapy, with frequent recurrences, and resistance to fluoroquinolones, which became potent inducers of CDAD. ${ }^{4,10-12}$ The same toxinotype III ribotype 027 hypervirulent strain has now been found in the United States, the United Kingdom and the Netherlands. ${ }^{13-16}$

A high short-term mortality was noted among CDAD patients in Sherbrooke, where $13.8 \%$ died within 30 days after diagnosis in 2003, compared with $4.7 \%$ in 1991/92 (these figures included both community-acquired and nosocomial cases). ${ }^{4}$ The proportion of deaths attributable to CDAD remains unknown, as does the excess mortality that might occur beyond the initial month after diagnosis. We thus conducted this study to measure mortality attributable to nosocomial CDAD, as well as the impact of CDAD on length of hospital stay, during 2003 and 2004 at the Centre hospitalier universitaire de Sherbrooke (CHUS), a 683-bed tertiary care hospital.

\section{Methods}

A database comprising all cases of CDAD diagnosed at CHUS since 199I is regularly updated by review of laboratory reports and discharge diagnoses and by periodic searches of the hospital's computerized medical records. ${ }^{4,11}$ The CHUS laboratory is the only one in the region performing the $C$. difficile cytotoxin assay. We considered a patient to have CDAD if he or she had diarrhea and met at least one of the following criteria: a stool specimen positive for $C$. difficile toxin by means of cytotoxin assay; changes on colonoscopy typical of pseudomembranous colitis; and histopathologic evidence of pseudomembranous 


\section{Editor's note}

A new strain of Clostridium difficile has been characterized as a hypervirulent toxinotype III ribotype 027 strain that produces levels of toxins A and B that are I6 to 23 times higher than those of previous toxinotype o strains. Does this strain cause more serious illness?

One year after diagnosis, $37 \%$ of I 6 I patients with CDAD had died, compared with $21 \%$ of 656 control subjects matched for age and disease severity, for a difference of $16.7 \%$ ( $95 \%$ confidence interval $8.6 \%-25.2 \%$ ). Patients with $\mathrm{CDAD}$ also had longer lengths of stay in hospital and were more likely to undergo emergency colectomy.

Implications for practice: Although this study could not compare the morbidity and mortality of patients with different strains of CDAD, it seems likely that the new strain is substantially more lethal than previous ones.

colitis. We considered a case of CDAD to be nosocomial if it developed more than 72 hours after hospital admission and up to 2 months after hospital discharge; all others were considered community-acquired cases.

We nested the current analysis within a cohort study of CHUS inpatients (aiming to identify risk factors for nosocomial CDAD), in which we reviewed the medical records of all

Table 1: Duration of hospital stay, per episode of care, and mortality in a cohort of patients admitted to the CHUS in 2003 and 2004, ${ }^{11}$ by age and Charlson Comorbidity Index score

No. (\%) of patients who died

\begin{tabular}{|c|c|c|c|c|}
\hline $\begin{array}{l}\text { Charlson score; } \\
\text { age group }\end{array}$ & $\begin{array}{c}\text { No. of } \\
\text { patients* }\end{array}$ & $\begin{array}{c}\text { Mean } \\
\text { hospital } \\
\text { stay, d }\end{array}$ & $\begin{array}{c}\text { Within } \\
30 \mathrm{~d} \text { after } \\
\text { admission }\end{array}$ & $\begin{array}{c}\text { Within } \\
1 \mathrm{yr} \text { after } \\
\text { admission }\end{array}$ \\
\hline \multicolumn{5}{|l|}{ Charlson score 0} \\
\hline $18-64 \mathrm{yr}$ & 1125 & 7.0 & $4 \quad(0.4)$ & $10 \quad(0.9)$ \\
\hline $65-74 \mathrm{yr}$ & 286 & 8.1 & $5 \quad(1.7)$ & $12 \quad(4.2)$ \\
\hline$\geq 75 \mathrm{yr}$ & 162 & 10.3 & $4 \quad(2.5)$ & $10 \quad(6.2)$ \\
\hline \multicolumn{5}{|c|}{ Charlson score 1-3 } \\
\hline $18-64 \mathrm{yr}$ & 1107 & 10.8 & $16 \quad(1.4)$ & $47 \quad(4.2)$ \\
\hline $65-74 \mathrm{yr}$ & 1220 & 13.6 & $42 \quad(3.4)$ & $131(10.7)$ \\
\hline$\geq 75 \mathrm{yr}$ & 1099 & 14.9 & $92 \quad(8.4)$ & $216(19.7)$ \\
\hline \multicolumn{5}{|c|}{ Charlson score 4-6 } \\
\hline $18-64 \mathrm{yr}$ & 299 & 15.7 & 14 & $39(13.0)$ \\
\hline $65-74 \mathrm{yr}$ & 659 & 17.4 & $47 \quad(7.1)$ & $156(23.7)$ \\
\hline$\geq 75 \mathrm{yr}$ & 803 & 19.2 & $82(10.2)$ & $214(26.7)$ \\
\hline \multicolumn{5}{|c|}{ Charlson score $\geq 7$} \\
\hline $18-64 \mathrm{yr}$ & 136 & 19.5 & 11 & 42 (30.9) \\
\hline $65-74 \mathrm{yr}$ & 292 & 23.0 & $32(11.0)$ & $108(37.0)$ \\
\hline$\geq 75 \mathrm{yr}$ & 233 & 21.7 & $38(16.3)$ & $86(36.9)$ \\
\hline
\end{tabular}

Note: CHUS = Centre hospitalier universitaire de Sherbrooke.

*The sum is greater than the total number of patients because some patients had more than one episode of care. adult patients admitted to hospital at least once in internal medicine, family medicine or gastroenterology wards between January 2003 and June 2004 and a random sample of $50 \%$ of patients admitted to hospital in the general surgery ward, as described in detail elsewhere. ${ }^{12}$ For each patient, we reviewed all hospital admissions during that period, regardless of the admitting service. Multiple hospital admissions for the same patient were considered to be a single "episode of care" if the interval between dates of discharge and subsequent readmissions was 60 days or less. ${ }^{12}$ Hospital admissions separated by more than 60 days were considered to be distinct episodes of care. To quantify the overall burden of comorbidities, we used the Charlson Comorbidity Index score, validated in numerous studies as a predictor of health care costs and mortality. ${ }^{17-20}$ The whole cohort comprised 56I9 patients with 742I episodes of care; for 509I of the episodes of care, the patient was admitted only once, and for 2330 the patient was admitted 2 or more times. ${ }^{12}$ As shown in Table I, the duration of hospital stay, per episode of care, and mortality were strongly influenced by age and Charlson Comorbidity Index score, as expected, which justified their subsequent use as matching criteria. Furthermore, within each age group or comorbidity index stratum, mortality was higher among patients who stayed longer in hospital (data not shown).

We included as case subjects only patients whose CDAD was diagnosed within an episode of care (a) during the first hospital admission, if the diagnosis was made more than 72 hours after admission, or (b) in the interval between the first and second hospital admissions or (c) during the first 3 days after the second hospital admission. We excluded patients whose CDAD was diagnosed less than 72 hours after their first hospital admission. In other words, we included only patients presumably exposed to $C$. difficile during their first hospital admission within an episode of care. Of 293 incident cases of CDAD in the whole cohort, I85 fulfilled this definition.

We wanted the control subjects to be as similar as possible to the case subjects for the presence of factors predictive of death and duration of hospital stay. For each case subject, we randomly selected up to 5 matched control subjects among all patients who did not acquire CDAD, were of the same sex and the same age $( \pm 2$ years), had an identical Charlson Comorbidity Index score and had remained in hospital at least as long as the corresponding case subject did until his or her CDAD was diagnosed (if the CDAD developed during the first hospital admission). For cases of CDAD that developed after the first admission, we selected similarly matched control subjects among patients whose duration of first hospital admission had been similar ( \pm 3 days) to that of the case subject. A patient could not be used as a control subject more than once. We excluded 24 case subjects because they had no suitable control subjects (e.g., I2 were 85 years or older, and II 
had a comorbidity score of 5 or more), which left I6I cases. We were able to find 656 control subjects.

Proportions were compared with the use of the $\chi^{2}$ test or, when numbers were small, the Fisher's exact test. Continuous data were compared with the use of Student's $t$ test or, if not normally distributed, the Kruskal-Wallis test. The probability of death over time was compared using the KaplanMeier method. For case subjects, day zero corresponded to the date of diagnosis of CDAD, whereas for their matched control subjects it was the day that they reached the same interval since admission as their case subject. The CHUS computerized medical records include the date of death even for events that occurred outside the hospital, from data provided by the Quebec Direction de l'État-Civil.

Table 2: Characteristics of inpatients in whom nosocomial Clostridium difficile-associated disease (CDAD) developed and of matched control subjects without CDAD

\begin{tabular}{|c|c|c|c|}
\hline \multirow[b]{2}{*}{ Characteristic } & \multicolumn{2}{|c|}{$\begin{array}{l}\text { Group; no. (\%) } \\
\text { of patients }\end{array}$} & \multirow[b]{2}{*}{$p$ value } \\
\hline & $\begin{array}{c}\text { Case } \\
\text { subjects } \\
n=161\end{array}$ & $\begin{array}{c}\text { Control } \\
\text { subjects } \\
n=656\end{array}$ & \\
\hline \multicolumn{4}{|l|}{ Sex } \\
\hline Female & $92(57.1)$ & $398(60.7)$ & \multirow{2}{*}{0.47} \\
\hline Male & $69(42.9)$ & $258(39.3)$ & \\
\hline \multicolumn{4}{|l|}{ Age, yr } \\
\hline $18-64$ & $16 \quad(9.9)$ & $64(9.8)$ & \multirow{3}{*}{0.99} \\
\hline $65-74$ & $62(38.5)$ & $257(39.2)$ & \\
\hline$\geq 75$ & $83(51.6)$ & $335(51.1)$ & \\
\hline \multicolumn{4}{|l|}{ Charlson score } \\
\hline 0 & $11 \quad(6.8)$ & $55 \quad(8.4)$ & \multirow{4}{*}{0.60} \\
\hline $1-3$ & $69(42.9)$ & $305(46.5)$ & \\
\hline $4-6$ & $59(36.6)$ & $225(34.3)$ & \\
\hline$\geq 7$ & $22(13.7)$ & $71(10.8)$ & \\
\hline $\begin{array}{l}\text { Had surgery during episode } \\
\text { of care }\end{array}$ & $34(21.1)$ & $130(19.8)$ & 0.80 \\
\hline \multicolumn{4}{|l|}{ Comorbidity } \\
\hline Ischemic heart disease & $73(45.3)$ & $338(51.5)$ & 0.19 \\
\hline Congestive heart failure & $23(14.3)$ & $134(20.4)$ & 0.10 \\
\hline Chronic renal failure & $35(21.7)$ & $131(20.0)$ & 0.70 \\
\hline Chronic lung disease & $60(37.3)$ & 209 (31.9) & 0.22 \\
\hline Diabetes mellitus & $40(24.8)$ & $186(28.4)$ & 0.43 \\
\hline $\begin{array}{l}\text { Peripheral vascular } \\
\text { disease }\end{array}$ & $66(41.0)$ & $221(33.7)$ & 0.10 \\
\hline Cerebrovascular disease & $46(28.6)$ & $155(23.6)$ & 0.23 \\
\hline Dementia & $28(17.4)$ & $85(13.0)$ & 0.29 \\
\hline $\begin{array}{l}\text { Nonmetastatic solid } \\
\text { tumour }\end{array}$ & $27(16.8)$ & $113(17.2)$ & 0.18 \\
\hline Metastatic solid tumour & $7 \quad(4.3)$ & $21 \quad(3.2)$ & 0.63 \\
\hline Leukemia or lymphoma & $4 \quad(2.5)$ & $16 \quad(2.4)$ & 1.00 \\
\hline Connective tissue disease & $7 \quad(4.3)$ & $46 \quad(7.0)$ & 0.98 \\
\hline Severe hepatic disease & 3 (1.9) & $15 \quad(2.3)$ & 1.00 \\
\hline
\end{tabular}

\section{Results}

As shown in Table 2, there were trivial differences in the sex distribution and the Charlson Comorbidity Index scores between the case and control subjects, owing to the fact that it was easier to find the maximal number of control subjects among women and among patients with a low comorbidity score. The mean age of the case and control subjects was 77.5 and 77.4 years respectively and the mean comorbidity score 3.8 and 3.5. The distribution of specific medical conditions did not differ statistically significantly between the case and control subjects.

Mortality among patients with CDAD and their matched control subjects differed considerably. At 30 days, $23.0 \%$ of the case subjects had died, compared with $7.0 \%$ of the control subjects ( $p<$ o.ooI, $\chi^{2}$ test) (Table 3 ). The differential mortality increased thereafter, with $36.0 \%$ of the case subjects and $14.6 \%$ of the control subjects having died at 6 months ( $p<0.00 I, \chi^{2}$ test) (Fig. I). The survival curves then converged to some extent, and at I2 months $37.3 \%$ of the case subjects and $20.6 \%$ of the control subjects had died, for a cumulative I-year attributable mortality of $\mathrm{I} 6.7 \%$ (95\% confi-

Table 3: Outcomes of inpatients in whom nosocomial Clostridium difficile-associated disease (CDAD) developed and of matched control subjects without CDAD

\begin{tabular}{|c|c|c|c|}
\hline \multirow[b]{2}{*}{ Outcome } & \multicolumn{2}{|c|}{$\begin{array}{l}\text { Group; no. (\%) } \\
\text { of patients }\end{array}$} & \multirow[b]{2}{*}{$p$ value } \\
\hline & $\begin{array}{c}\text { Case } \\
\text { subjects } \\
n=161\end{array}$ & $\begin{array}{c}\text { Control } \\
\text { subjects } \\
n=656\end{array}$ & \\
\hline \multicolumn{4}{|l|}{ Death } \\
\hline Within $30 \mathrm{~d}$ & $37(23.0)$ & $46 \quad(7.0)$ & $<0.001$ \\
\hline Within $90 \mathrm{~d}$ & $48(29.8)$ & 75 (11.4) & $<0.001$ \\
\hline Within 6 mo & $58(36.0)$ & $96(14.6)$ & $<0.001$ \\
\hline Within $1 \mathrm{yr}$ & $60(37.3)$ & $135(20.6)$ & $<0.001$ \\
\hline $\begin{array}{l}\text { Duration of first hospital } \\
\text { admission, mean, } d\end{array}$ & 25.5 & 18.8 & $<0.001$ \\
\hline \multicolumn{4}{|l|}{ Second admission } \\
\hline Did occur & $60(37.3)$ & $151(23.0)$ & $<0.001$ \\
\hline Duration, mean, $d$ & 16.8 & 14.4 & 0.59 \\
\hline \multicolumn{4}{|l|}{ Third admission } \\
\hline Did occur & $17(10.6)$ & $39 \quad(5.9)$ & 0.06 \\
\hline Duration, mean, $d$ & 14.1 & 11.4 & 0.22 \\
\hline \multicolumn{4}{|l|}{ Fourth admission } \\
\hline Did occur & $7 \quad(4.3)$ & $12(1.8)$ & 0.08 \\
\hline Duration, mean, $d$ & 11.1 & 12.7 & 0.42 \\
\hline $\begin{array}{l}\text { Total duration in } \\
\text { hospital, mean, } d\end{array}$ & 33.7 & 23.1 & $<0.001$ \\
\hline \multicolumn{4}{|l|}{ Admission to ICU } \\
\hline All causes & $51(31.7)$ & $158(24.1)$ & 0.06 \\
\hline CDAD-related & $16 \quad(9.9)$ & NA & \\
\hline CDAD-related colectomy & $4 \quad(2.5)$ & NA & \\
\hline
\end{tabular}

Note: $\mathrm{NA}=$ not applicable. 
dence interval 8.6\%-25.2\%). Table 3 also shows the duration of hospital stays for the case and control subjects during an episode of care. The occurrence of CDAD increased the duration of the first admission by 6.7 days on average; it also had an impact on the need for a second, third and fourth hospital admission. Overall, patients with CDAD spent I0.7 days longer in hospital than the control subjects; $9.9 \%$ needed admission to an intensive care unit for CDAD-related care (where they spent 6.9 days on average), and $2.5 \%$ needed an emergency colectomy (Table 3).

A total of 630 cases of nosocomial CDAD occurred among all CHUS patients during 2003 and 2004. Extrapolating to this group the mean excess duration of hospital stay, we calculated that the epidemic generated 6716 days of hospital care

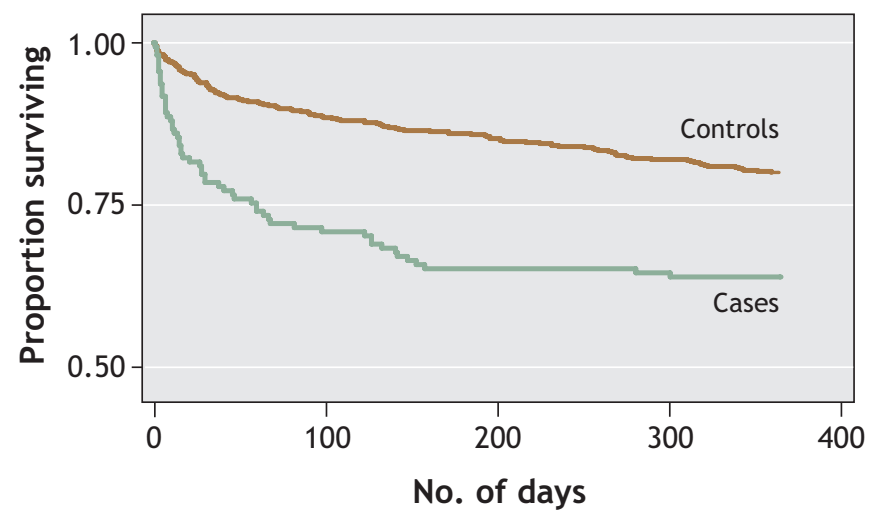

Fig. 1: Kaplan-Meier plot showing probability of death since diagnosis among inpatients in whom nosocomial Clostridium difficile-associated disease (CDAD) developed and among matched control subjects without CDAD. No. of days = time since diagnosis of CDAD (cases) or time since reaching the same interval after admission (controls). and that, on average, 9 hospital beds were used each day to provide care to $\mathrm{CDAD}$ patients.

We calculated the mortality at 30 days and at 12 months among the case and control subjects after stratifying for age and Charlson Comorbidity Index score (Table 4). There was no excess mortality attributable to nosocomial CDAD among patients aged less than 65 years or among those without comorbidities (Charlson score $=0$ ). The attributable mortality was substantial both among patients aged $65-74$ years and among those aged 75 years or more as well as in all 3 categories of comorbidity scores for patients with at least one comorbidity.

\section{Interpretation}

The most important finding of our study was the high excess mortality among hospital patients with CDAD compared with matched control subjects, who should otherwise have experienced approximately the same mortality. This attributable mortality appeared in the first month following diagnosis. For many elderly patients, CDAD and its common relapses ${ }^{11}$ lead to a cascade of interrelated complications that are ultimately fatal. Some outcomes occur because of a direct complication of CDAD (septic shock, perforation), whereas for others the pathway to death is more complex: for example, a myocardial infarction triggered by hypovolemia, a pulmonary embolism following prolonged immobilization, or a second nosocomial infection. Our approach provided an estimate of the overall excess mortality attributable to CDAD among elderly patients with several comorbidities, avoiding the biases inherent in relying on a reviewer's judgment to determine whether a given death was caused directly or indirectly by CDAD. ${ }^{7}$ The survival curves in Fig. I suggest that, for deaths that occurred more than 30 days after diagnosis, CDAD merely precipitated an event that would have occurred in any case a few months later owing to the patient's comorbidities. However, about onesixth of the inpatients with CDAD died when they would have

Table 4: Mortality at 30 days and 1 year among inpatients in whom nosocomial Clostridium difficile-associated disease (CDAD) developed and in matched control subjects without CDAD, by age and Charlson Comorbidity Index score

\begin{tabular}{|c|c|c|c|c|c|c|}
\hline Variable & $\begin{array}{c}\text { No. (\%) of } \\
\text { case subjects }\end{array}$ & $\begin{array}{c}\text { No. (\%) of } \\
\text { control subjects }\end{array}$ & $\begin{array}{c}\text { Attributable } \\
\text { mortality }(95 \% \mathrm{Cl}), \%\end{array}$ & $\begin{array}{c}\text { No. }(\%) \text { of } \\
\text { case subjects }\end{array}$ & $\begin{array}{c}\text { No. }(\%) \text { of } \\
\text { control subjects }\end{array}$ & $\begin{array}{c}\text { Attributable } \\
\text { mortality }(95 \% \mathrm{Cl}), \%\end{array}$ \\
\hline \multicolumn{7}{|l|}{ Age, yr } \\
\hline $18-64$ & $1 / 16 \quad(6.3)$ & $2 / 64$ & $3.2(-7.4$ to 29.3$)$ & $1 / 16 \quad(6.3)$ & $7 / 64 \quad(10.9)$ & $-4.7(-22.0$ to 17.1$)$ \\
\hline $65-74$ & $12 / 62(19.4)$ & $13 / 257 \quad(5.1)$ & 14.3 (5.0 to 26.9 ) & $23 / 62(37.1)$ & $41 / 257(16.0)$ & 21.1 (8.4 to 35.0$)$ \\
\hline \multicolumn{7}{|c|}{$\begin{array}{l}\text { Charlson } \\
\text { Comorbidity } \\
\text { Index score }\end{array}$} \\
\hline 0 & $0 / 11(0)$ & $1 / 55$ & $-1.8(-30.4$ to 11.0$)$ & $0 / 11(0)$ & $1 / 55$ & $-1.8(-30.4$ to 11.0$)$ \\
\hline $1-3$ & $16 / 69(23.2)$ & $16 / 305 \quad(5.2)$ & $17.9 \quad(8.4$ to 30.1$)$ & $20 / 69(29.0)$ & 48/305 (15.7) & 13.3 (2.2 to 26.2 ) \\
\hline
\end{tabular}

Note: $\mathrm{Cl}=$ confidence interval. 
otherwise been expected to survive at least I year. This represents a major change in the epidemiology and pathogenicity of C. difficile, which until recently was considered a nuisance pathogen with no measurable impact on mortality. ${ }^{21}$

Our study had limitations. We were unable to find 5 control subjects for each case subject, which resulted in minor differences between the case and control subjects in sex distribution and comorbidity scores. However, within the whole cohort, mortality did not differ between men and women, and differences in comorbidity scores between case and control subjects were probably too modest to bias our measure of attributable mortality. Another limitation was that we nested our current analysis within a larger cohort study examining risk factors for CDAD among patients admitted to hospital at least once in internal medicine, family medicine, gastroenterology or general surgery wards. In our hospital, patients admitted to these wards are older than those admitted by other medical or surgical subspecialty services (mean $65.8 \mathrm{v}$. 58.4 years). As a consequence, the mean age of the r6I case subjects in the current study was 77.4 years, compared with 72.3 years for all 630 cases of nosocomial CDAD diagnosed at the CHUS during 2003 and 2004. Many cases of nosocomial $\mathrm{CDAD}$ and of CDAD-attributable deaths occurred in very old, debilitated patients for whom the attending physician and the family jointly decided not to provide aggressive care. We might have calculated a somewhat lower attributable mortality had we conducted the study within a cohort of all adult, nonpsychiatric, nonobstetric admissions, thus including patients less than 65 years of age with fewer comorbidities for whom intensive care (or a colectomy) would be contemplated. However, the 30-day all-cause mortality of $23.0 \%$ among the cases of nosocomial CDAD in the current analysis was identical to that among all nosocomial CDAD cases reported by the Quebec provincial surveillance system. ${ }^{7}$

We measured the attributable mortality during an epidemic of CDAD caused by a hypervirulent toxinotype III ribotype 027 strain, which produced levels of toxins A and B I6-23 times higher than those of contemporary toxinotype o strains and represented two-thirds of our isolates of hospitalacquired $C$. difficile. ${ }^{9}$ Thus, our results cannot be extrapolated to centres outside Quebec, where the strain might be absent or uncommon. However, the same strain has been found in several US states and more recently in the United Kingdom and the Netherlands. ${ }^{14-16}$ In England, Wales and Northern Ireland, the number of cases of CDAD reported doubled between 2001 and 2004; ${ }^{13}$ in 2004, the nationwide incidence of CDAD among people aged 75 years or more was 678 per IOo $000,{ }^{13,14}$ and the rates of nosocomial CDAD were similar to those reported in Quebec. ${ }^{22}$ Although improved reporting might explain some of this rising incidence, preliminary evidence suggests that the ribotype 027 strain has spread to at least 15 hospitals in the United Kingdom. ${ }^{23}$

Because the risk of CDAD is influenced by the duration of hospital stay (which reflects exposure), ${ }^{12}$ a longer hospital stay could be the cause rather than the consequence of CDAD. To avoid such a bias, we selected as case subjects only patients who had probably been exposed to $C$. difficile during their first hospital admission within an episode of care, and as control subjects only patients without CDAD who had been in hospital at least as long as their matched case subject had been until the day CDAD was diagnosed. Previous studies of the effect of CDAD on costs and durations of hospital stay did not distinguish between the time that case subjects spent in hospital before and after the diagnosis of CDAD. ${ }^{21,24,25}$

Despite the limitations of our study, our results can be used to estimate the approximate total excess mortality caused by the $C$. difficile epidemic in Quebec (population 7.5 million). A review of an administrative database of the Quebec ministry of health ${ }^{5}$ revealed that 773I cases of nosocomial CDAD were documented during the fiscal year 2003/04. Data for 2004/05 are not yet known, but preliminary results from a provincial surveillance system suggest that the incidence was similar. ${ }^{7}$ Based on a conservative estimate of I4 000 cases of nosocomial CDAD for these 2 years and the $95 \%$ confidence intervals around our measures of attributable mortality, and assuming that throughout Quebec $75 \%$ of the cases of nosocomial CDAD occur among patients aged 65 year or more, we calculated that, for the whole of Quebec, between 1000 and 3000 patients might have died so far as a result of this epidemic.

A lingering question that remains unanswered is why this strain of $C$. difficile spread so extensively within and between hospitals in Quebec, while dissemination of the same hypervirulent, and presumably highly infectious, strain seems to have been more limited in the rest of Canada and the United States. ${ }^{15,26,27}$ There is no evidence that Quebec differs from other jurisdictions in North America with regard to the size of its population of elderly inpatients or to the use of antibiotics. In 2003 and 2004, respectively, 686 and 663 prescriptions of antibiotics per 1000 inhabitants were delivered in retail pharmacies of Quebec, compared with 763 and 737 in the rest of Canada. ${ }^{28}$ Assuming a mean duration of Io days per prescription, use of antibiotics in Quebec corresponded to I8.5 defined daily doses per 1000 inhabitants-days, a figure similar to that in British Columbia ${ }^{29}$ and to the median in 26 European countries. ${ }^{30}$ The lack of investment in our hospitals infrastructure over several decades, with shared bathrooms being the rule rather than the exception, may have facilitated the transmission of this spore-forming pathogen, which can survive on environmental surfaces for months. Providing modern medical care within hospitals built a century ago is no longer acceptable.

\section{This article has been peer reviewed.}

From the Department of Microbiology and Infectious Diseases, University of Sherbrooke (Pépin, Valiquette), and the Department of Pharmacy, Centre hospitalier universitaire de Sherbrooke (Cossette), Sherbrooke, Que.

Competing interests: None declared.

Contributors: Jacques Pépin was responsible for the conception of the study, supervised data collection, conducted the analyses and wrote the first draft of the manuscript. Louis Valiquette and Benoit Cossette contributed to data analysis and revised subsequent versions of the manuscript. All of the authors contributed to the final version of the manuscript.

Acknowledgements: We are indebted to Bruno Hubert, Philippe De Wals and Clifford McDonald for their thoughtful comments on an earlier draft of this manuscript. 


\section{REFERENCES}

I. Alfa M, Du T, Beda G. Survey of incidence of Clostridium difficile infection in Canadian hospitals and diagnostic approaches. J Clin Microbiol 1998;36:2076-80.

2. Eggertson L. C. difficile: by the numbers. $C M A J 2004 ; 17 \mathrm{I}(\mathrm{II}): 133 \mathrm{I}-2$.

3. Valiquette L, Low DE, Pépin J, McGeer A. Clostridium difficile infection in hospitals: a brewing storm. $C M A J$ 2004;I7I(I):27-9.

4. Pépin J, Valiquette L, Alary ME, Villemure P, Pelletier A, Forget K, et al. Clostridium difficile-associated diarrhea in a region of Quebec from I991 to 2003: a changing pattern of disease severity. CMAJ 2004;I7I(5):466-72.

5. Gaulin $\mathrm{C}$, Hubert B, Allard R. Évolution des infections à C. difficile dans les centres hospitaliers québécois I999-2003 à partir du fichier Med-Echo [abstract]. Special symposium on $C$. difficile, Association des Médecins Microbiologistes-Infectiologues du Québec, Montréal, September 2004

6. Institut National de Santé Publique. La surveillance des diarrhées associées aux infections à Clostridium difficile. Deuxième rapport tiré du système de surveillance des infections à Clostridium difficile (SSICD) de l'Institut National de Santé Publique du Québec. Available: www.inspq.qc.ca/pdf/publications/370-Resultats CDifficile-22Aout2004-05Fevrier2005.pdf (accessed 2005 Sept 6).

7. Direction risques biologiques, environnementaux et occupationnels et Laboratoire de santé publique du Québec. Surveillance des diarrhées associées à Clostridium difficile au Québec: Bilan du 22 août au 3 I mars 2005. Sainte-Foy (QC): Institut national de santé publique du Québec; 2005. Available: www.inspq.qc.ca/pdf/publications 1389-SurveillanceCDifficile_Bilan22aouto4-3Imarso5.pdf (accessed 2005 Sept 20).

8. Dial S, Alrasadi K, Manoukian C, Huang A, Menzies D. Risk of Clostridium difficile diarrhea among hospital inpatients prescribed proton pump inhibitors: cohort and case-control studies. $C M A J$ 2004;17I(I):33-8

9. Warny M, Pépin J, Fang A, Killgore G, Thompson A, Brazier J, et al. Toxin production by an emerging strain of Clostridium difficile associated with outbreaks of severe disease in North America and Europe. Lancet 2005;366:1079-84.

ro. Hospitalisations pour des soins de courte durée dans les installations de soins généraux et spécialisés participant au système Med-Écho selon le groupe d'âge de I'usager, au Québec, I992-I993 et 2003-04. Québec (QC): Ministère de la Santé et des Services sociaux du Québec; 2005. Available: www.msss.gouv.qc.ca/statistiques /produc_util.html (accessed 2005 Sept 20).

II. Pépin J, Alary ME, Valiquette L, Raiche E, Ruel J, Fulop K, et al. Increasing risk of relapse after treatment of Clostridium difficile colitis in Quebec, Canada. Clin Infect Dis 2005;40:159I-7

I2. Pépin J, Saheb N, Coulombe MA, Alary ME, Corriveau MP, Authier S, et al. Emergence of fluoroquinolones as the predominant risk factor for Clostridium difficile associated diarrhea: a cohort study during an epidemic in Quebec. Clin Infect Dis 2005 Sept 20 [Epub ahead of print]. Available: www.journals.uchicago.edu/CID /journal/rapid.html (accessed 2005 Sept 2I).

I3. Health Protection Agency. Voluntary reporting of Clostridium difficile, England, Wales and Northern Ireland: 2004. Commun Dis Rep CDR Wkly 2005;15:I-3. Available: www.hpa.org.uk/cdr/archives/2005/cdr2005.pdf (accessed 2005 Sept 20).

I4. Health Protection Agency. Outbreak of Clostridium difficile infection in a hospital in south east England. Commun Dis Rep CDR Wkly 2005;15:2-3. Available: www.hpa.org.uk/cdr/archives/2005/cdr2405.pdf (accessed 2005 Sept 6).

I5. McDonald LC, Killgore GE, Thompson A, Johnson S, Gerding DN; C. difficile Investigation Team. Emergence of an epidemic strain of Clostridium difficile in the
United States 200I-4: potential role for virulence factors and antimicrobial resistance traits [abstract LB-2]. 42nd annual meeting of the Infectious Diseases Society of America, Boston, October 2004

I6. Van Steenbergen J, Debast S, van Kregten E, van den Berg R, Notermans D, Kuijper E. Isolation of Clostridium difficile ribotype 027, toxinotype III in the Netherlands after increase in C. difficile associated diarrhoea. Eurosurveillance Wkly 2005; I0. Available: www.eurosurveillance.org/ew/2005/050714.asp (accessed 2005 Sept 20).

I7. Charlson M, Szatrowski TP, Peterson J, Gold J. Validation of a combined comorbidity index. JClin Epidemiol 1994;47:1245-5I.

I8. Perkins AJ, Kroenke K, Unutzer J, Katon W, Williams JW, Hope C, et al. Common comorbidity scales were similar in their ability to predict health care costs and mortality. J Clin Epidemiol 2004;57:1040-8.

I9. Deyo RA, Cherkin DC, Ciol MA. Adapting a clinical comorbidity index for use with ICD-9-CM administrative database. J Clin Epidemiol I992;45:613-9.

20. Schneeweiss S, Seeger JD, Maclure M, Wang PS, Avorn J, Glynn RJ. Performance of comorbidity scores to control for confounding in epidemiologic studies using claims data. Am J Epidemiol 200I;154:854-64.

2I. Kyne L, Hamel MB, Polavaram R, Kelly CP. Health care costs and mortality associated with nosocomial diarrhea due to Clostridium difficile. Clin Infect Dis 2002;34:346-53.

22. Department of Health. Results of the first year of mandatory Clostridium difficile reporting: January to December 2004. Commun Dis Rep CDR Wkly 2005;I5(34):I3. Available: www.dh.gov.uk/assetRoot/04/1r/84/79/04II8479.pdf (accessed 2005 Sept 20).

23. ProMED-mail. Clostridium difficile, increased virulence - UK (England) (05) ProMED-mail 2005 June 30: 20050630.1843. Available: www.promedmail.org Accessed 6 September 2005 .

24. Riley TV, Codde JP, Rouse IL. Increased length of hospital stay due to Clostridium difficile associated diarrhoea. Lancet I995;345:455-6.

25. Wilcox MH, Cunniffe JG, Trundle C, Redpath C. Financial burden of hospital-acquired Clostridium difficile infection. J Hosp Infect I996;34:23-30.

26. Dallal RM, Harbrecht BG, Boujoukas AJ, Sirio CA, Farkas LM, Lee KK, et al. Fulminant Clostridium difficile: an underappreciated and increasing cause of death and complications. Ann Surg 2002;235:363-72.

27. Muto CA, Pokrywka M, Shutt K, Mendelsohn AB, Nouri K, Posey K, et al. A large outbreak of Clostridium difficile-associated disease with an unexpected proportion of deaths and colectomies at a teaching hospital following increased fluoroquinolone use. Infect Control Hosp Epidemiol 2005;26:273-80.

28. IMS Health. Canadian CompuScript, Anti-infective Class 2003-2004. Montreal, Canada.

29. Patrick DM, Marra F, Hutchinson J, Monnet DL, Ng H, Bowie WR. Per capita antibiotic consumption: how does a North American jurisdiction compare with Europe? Clin Infect Dis 2004;39:II-7.

30. Goossens H, Ferech M, Vander Stichele R. Elseviers M for the ESAC Project Group. Outpatient antibiotic use in Europe and association with resistance: a cross-national database study. Lancet 2005;365:579-87.

Correspondence to: Dr. Jacques Pépin, Centre hospitalier universitaire de Sherbrooke, 300I, $\mathrm{I}^{\mathrm{e}}{ }^{\mathrm{A}}$ Avenue Nord, Sherbrooke QC $\mathrm{J}_{\mathrm{I} H}$ 5N4; fax 8Ig 820-645I; jacques.pepin@usherbrooke.ca 